\title{
THE IMPORTANCE OF VULNERABLE AREAS WITH POTENTIAL TOURISM DEVELOPMENT: A CASE STUDY OF THE BOHEMIAN FOREST AND SOUTH BOHEMIA TOURISM REGIONS
}

Josef Navrátil, Miha Lesjak, Kamil Pícha, Stanislav Martinát, Jana Navrátilová, Vivian L. White Baravalle Gilliam, Jaroslav Knotek, Tomáš Kučera, Roman Švec, Zuzana Balounová, Josef Rajchard

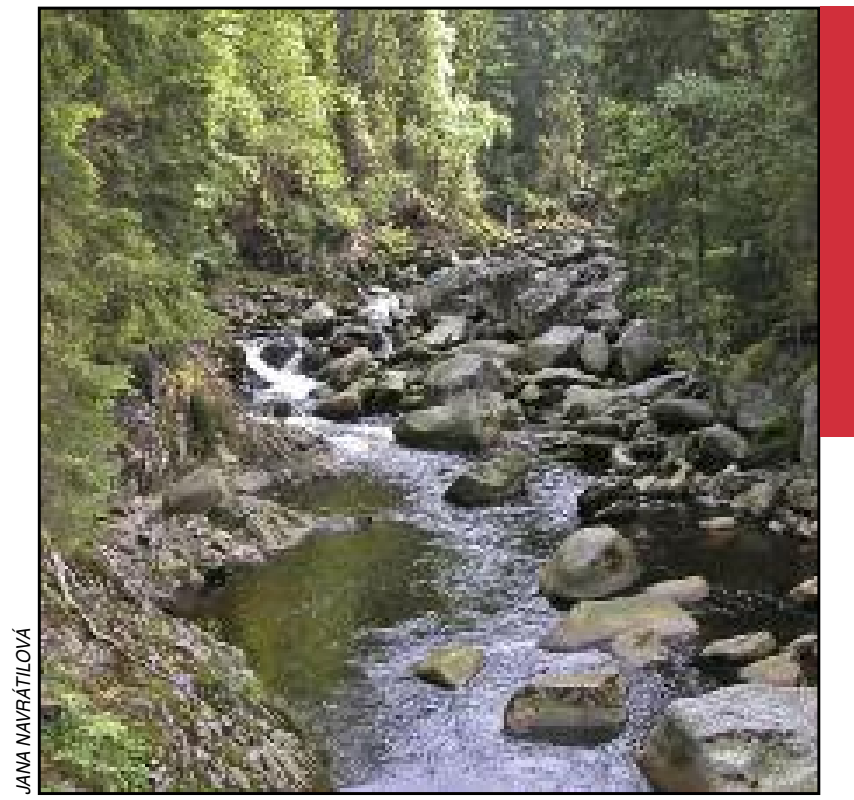

Vydra River in the Bohemian Forest in 2008. 


\section{The importance of vulnerable areas with potential tourism development: a case study of the Bohemian forest and South Bohemia tourism regions}

DOI: http://dx.doi.org/10.3986/AGS54108

UDC: $913: 338.48(437.3)$

$502.1: 338.48(437.3)$

COBISS: 1.01

ABSTRACT: The significance of the vulnerability of nature-rich areas with high development potential for tourism was studied using three types of data: 1) spatial distribution of tourist attractions, 2) the appeal level of these attractions, and 3 ) the number of visitors. The Bohemian Forest and South Bohemia were chosen as study areas. Nine types of landscape spatial appeal were identified in the study area. Two most important types were defined based on their appeal where there are rare relic features in the natural environment dominated by the presence of peat bogs and natural habitats with scrub undergrowth or virgin forests. These types were also found in the areas with the greatest potential for tourism development. However, these areas are also the most important from the point of view of nature conservation and landscape protection in Central Europe.

KEY WORDS: geography, landscape, tourism, Czech Republic

ADDRESSES:

Josef Navrátil, Ph. D.

Department of biological disciplines, faculty of agriculture,

University of South Bohemia in České Budějovice

Studentská 13, CZ - 37005 České Budějovice, Czech Republic

E-mail: josefnav@gmail.com

Miha Lesjak, M. Sc.

Faculty of tourism studies - Turistica, Portorož

Univesity of Primorska, Koper,

Obala 11a, SI - 6320 Portorož, Slovenia

E-mail: miha.lesjak@turistica.si

Kamil Pícha, Ph. D.

Department of trade and tourism, faculty of economics,

University of South Bohemia in České Budějovice

Studentská 13, CZ - 37005 České Budějovice, Czech Republic

E-mail:kpicha@ef.jcu.cz

Stanislav Martinát, M. Sc.

Department of economics, school of business administration in karviná,

Silesian University in Opava,

Univerzitní nám. 1934/3, CZ - 73340 Karviná, Czech Republic

E-mail: martinat@opf.slu.cz

Jana Navrátilová, Ph. D.

Department of botany and zoology, faculty of science,

Masaryk University

Kotlářská 2, CZ - 61137 Brno, Czech Republic

E-mail: jananav@gmail.com 


\section{Vivian L. White Baravalle Gilliam}

Institute of technology and business in české budějovice

Okružní 517/10, CZ - 37001 České Budějovice, Czech Republic

E-mail: vivian@mail.vstecb.cz

\section{Jaroslav Knotek, Ph. D.}

Department of applied and landscape ecology, faculty of agronomy,

Mendel University in Brno

Zemědělská 1, CZ - 61300 Brno, Czech Republic

E-mail: jarda.knotek@uake.cz

\section{Tomáš Kučera, Ph. D.}

Department of ecosystem biology, faculty of science,

University of South Bohemia in Ceské Budějovice

Branišovská 31, CZ - 37005 České Budějovice, Czech Republic

E-mail: kucert00@prf.jcu.cz

\section{Roman Švec, Ph. D.}

Institute of technology and business in české budějovice

Okružní 517/10, CZ - 37001 České Budějovice, Czech Republic

E-mail: svec.roman78@gmail.com

\section{Zuzana Balounová, Ph. D.}

Department of biological disciplines, faculty of agriculture, University of South Bohemia in České Budějovice

Studentská 13, CZ - 37005 České Budějovice, Czech Republic E-mail: baloun@zf.jcu.cz

\section{Josef Rajchard, Ph. D.}

Department of biological disciplines, faculty of agriculture, University of South Bohemia in České Budějovice

Studentská 13, CZ - 37005 České Budějovice, Czech Republic

E-mail: rajchard@zf.jcu.cz 


\section{Introduction}

The opportunity to develop recreational activities is among the main motives for creating national parks (Williams 1998) and tourism remains an important justification for park creation and development today (Hall and Lew 2009). Similar to the rural environment, these spaces offer opportunities for refreshment to people living in urban spaces that lack opportunities for everyday contact with the »environment of nature (Olwig and Olwig 1979). Rural areas became an important space of large-scale tourism in the 1950s and 1960s for this reason (Hall and Page 2006), and then (in part since the 1990s) they also became a destination of ecotourism activities (Weaver 2006). For instance, in the United States the National Park System is part of the country's greatest tourist attractions, appealing to both domestic and international visitors (Goeldner and Ritchie 2009).

The ongoing degradation of the environment and its urbanization are further increasing the value of the pleasure periphery in tourism (Bushell et al. 2007). These kinds of environments are then increasingly exposed to pressures resulting from conflicts among different types of use of such areas (Jamal et al. 2002; McClanahan et al. 2009). The risk of the degrading impact of tourism increases with the rising number of visitors (Geneletti and Dawa 2009; Heydendael 2002; Marion and Leung 2001; Nepal and Nepal 2004; Vasiljević et al. 2011), which consequently results in people experiencing less satisfaction from the visit (Juutinen 2011). Disregarding the other influences, three interests clash at the intersection of these vulnerable areas from the tourism point of view: nature conservation (Hall and Lew 2009), ecotourism, and large-scale tourism activities (Epler Wood 2002; Weaver 2006). According to Anderson and Brown (1984), one of the main tools for preventing conflicts is recreational displacement - that is, a way in which all three interest groups are able to achieve maximal satisfaction (Hall and Page 2006).

Studies in tourism locations and the importance of these tourist attractions as location factors are the main areas of research in tourism geography (Williams 1998). This has taken place since the beginning of the twentieth century (Benthien 1997). The key approaches were crystallized in the late 1960s and the early 1970s (Hall and Page 2006). Studies and dissertations on these problems agree that core resources are fundamental for localization in tourism (following Ritchie and Crouch 2003), and the highest importance within these core resources is attributed to undeveloped recreation resources (Chubb and Chubb 1981) of natural or cultural origin (Ritchie and Crouch 2003). The basis for visitation management in particular locations of destination created by knowledge of the distribution of attractions (Kostrowicky 1970) and the extent of their importance for visitors (Linton 1968). This knowledge allows management to make decisions directed aimed at satisfying these two contradictory requirements. It is essential that these attractions not be performed separately in the space, but that they create spatial systems of tourism (Lau and McKercher 2007) that are geographically recognizable (Wall 1997) as the spatial types of a recreational landscape (Burger 2000). These types provide various motives for different types of visitors (Horner and Swarbrooke 1996) and similarly show the various values of habitats for nature conservation (Kučera 2005).

Accordingly, the main aim of this article is to present testing methods for evaluating the relative importance of vulnerable areas for tourism development in large areas.

\section{Methodology}

\subsection{Study Area}

This article examines the South Bohemian Region (Cz. Jihočesky kraj), an area with a temperate climate in the southern part of the Czech Republic along the border with Germany (Bavaria) and Austria (Upper Austria; Cetkovský et al. 2007; Švec et al. 2012). The selected area comprises two tourism marketing regions: South Bohemia and the Bohemian Forest (Cz. Šumava, Figure 1). The territory extends throughout a rather geographically diversified part of the Czech Republic. Bohemian Forest National Park (Cz. Národní park Šumava), the Třeboň Protected Landscape Area (Cz. Chráněná krajinná oblast Třeboňsko), the Bohemian Forest Protected Landscape Area (Cz. Chráněná krajinná oblast Šumava), and the Blanský Forest Protected Area (Cz. Chráněná krajinná oblast Blanský les; Figure 2) are the largest conservation areas in the region studied (Navrátil et al. 2012b). 


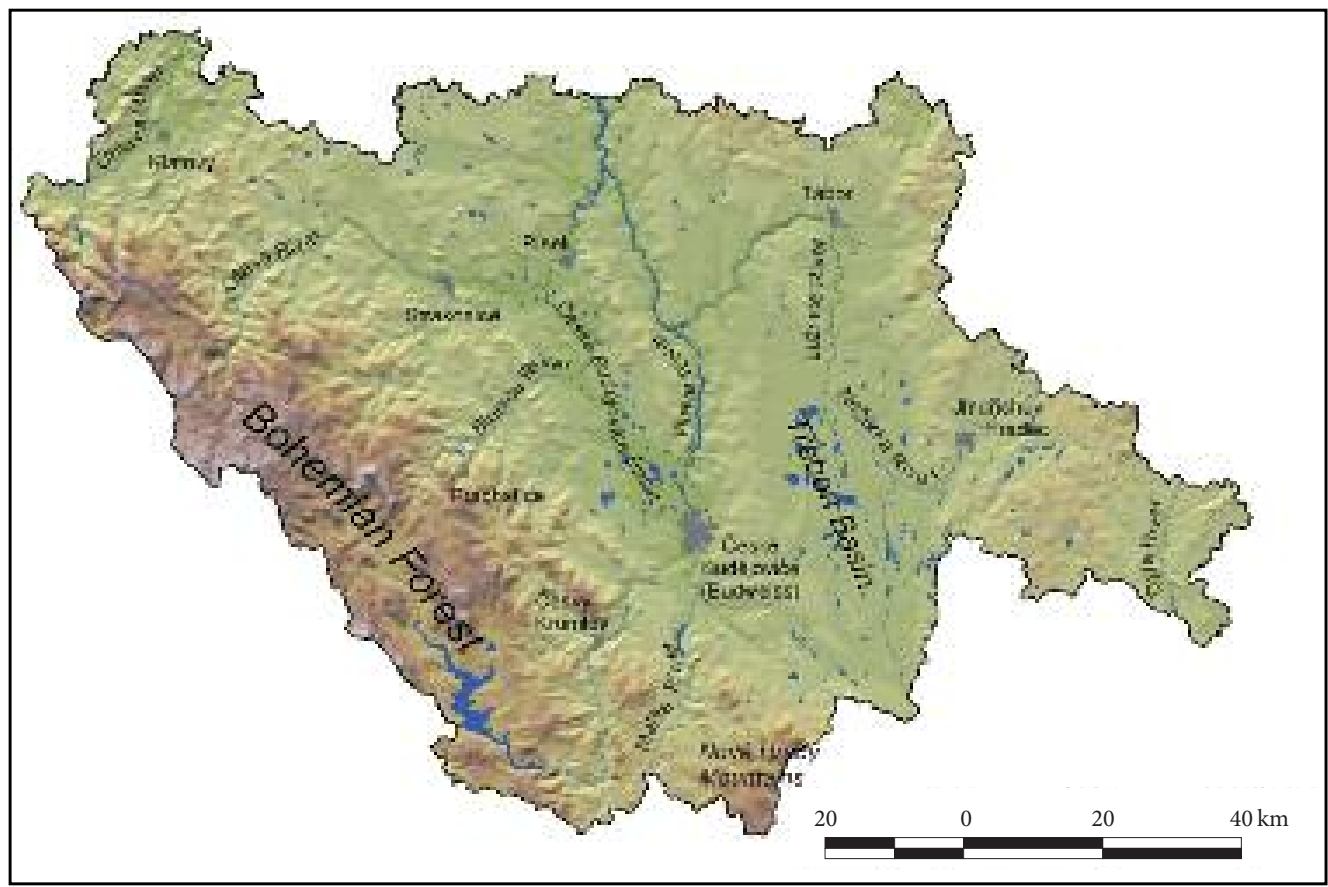

Figure 1: Topography of the study area (ArcData Praha, s. r. ..).

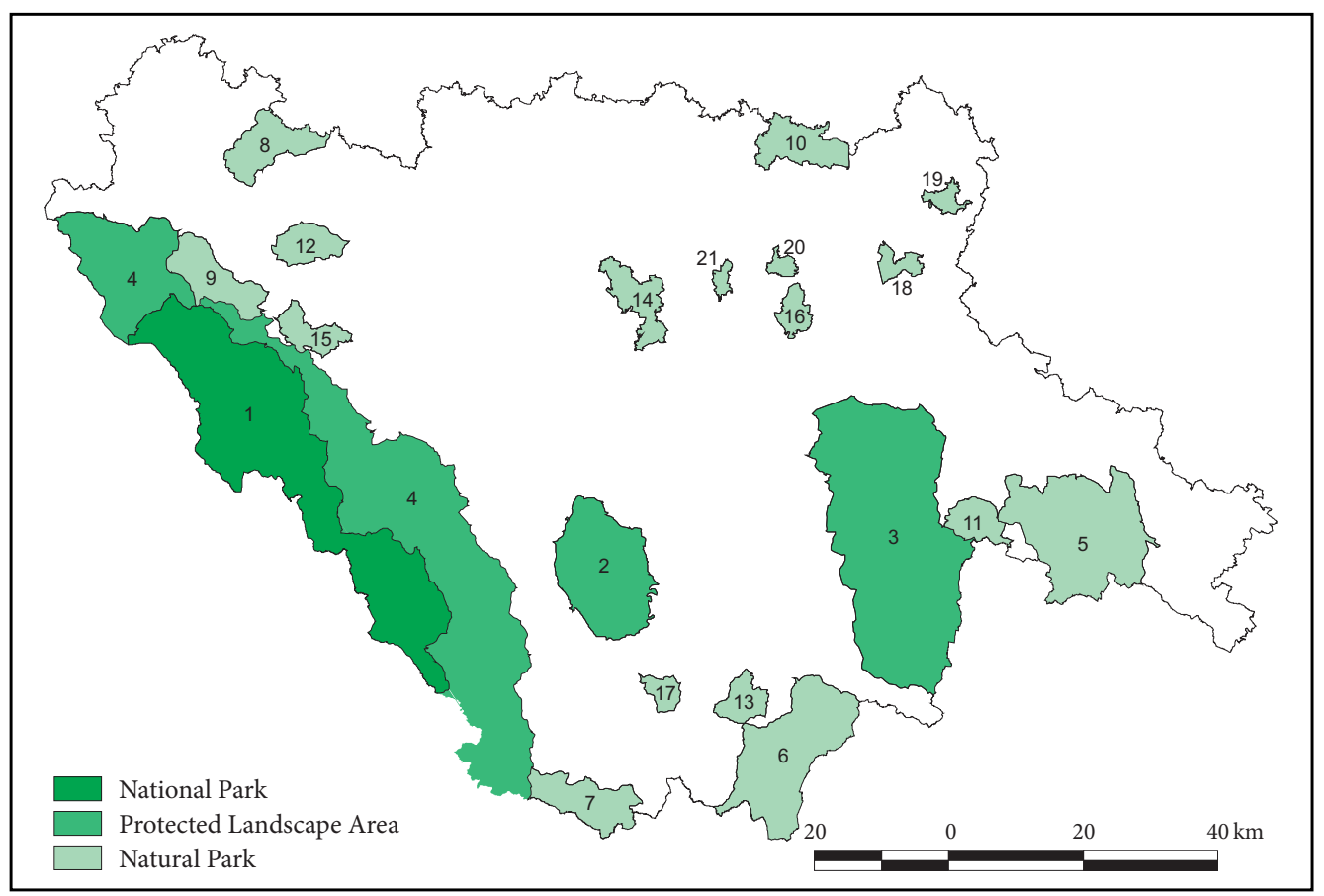

Figure 2: Conservation areas within the study area (1 - Bohemian Forest National Park, 2 - Blanský Forest Protected Area, 3 - Třeboň Protected Landscape Area, 4 - Bohemian Forest Protected Landscape Area, 5-21 - natural parks). 


\subsection{Data Collection}

It was necessary to gather three types of data to accomplish the defined aim of this article: the spatial distribution of tourist attractions, the appeal level of these attractions, and the number of visitors in individual territorial units of the study area.

A database of potential attractions was created to identify the distribution of tourist attractions. The individual attractions were identified based on tourism geography literature (Mariot 1983; Ritchie and Crouch 2003; Hall and Page 2006; Kušen 2010). The database only covers permanent attractions; that is, those that cannot be moved or quickly rebuilt based on tourist demand (Gunn 1997). Primarily, this involves components of appearance, culture, and history (Ritchie and Crouch 2003). Sixty-nine attraction types were localized: those found statistically important for further calculations are shown in Table 1 (for the entire list, see Navrátil et al. 2013a).

The appeal of the destinations was investigated for partial segments of demand. They were identified by surveying visitors at important sights and areas within the study area and model segments. Visitors to the study area were surveyed on roughly sixty attractions in the study area from 2009 to 2011. A database of 3,776 completed questionnaires was developed. In addition, an experiment was carried out on three model segments of tourists on the eco-tourism/mass-tourism continuum. Students were utilized for this research (Palmer and Hofmann 2001). We chose university students as model segments:

- business students representing »large-scale tourists, «

- ecology students representing »eco-tourists, « and

- agriculture students representing »neutral tourists«; (these methods are based on Navrátil et al. 2013b).

The students filled out 396 questionnaires (the questionnaire return rate was $61 \%$ ). The intensity of recreational activities during leisure activities away from a permanent residence was used as the basic element of segment identification: the questioning tool used is described in detail in Navrátil et al. (2010). The questionnaire was filled out by students representing particular model types of visitors. The students were also asked to complete a questionnaire seeking to identify the amount of appeal of the individual attractions. Q-sort methodology was used (Doody et al. 2009). A setup of eleven columns was used (Barry and Proops 1999; Steelman and Maguire 1999). The respondents were asked to sort the photographs of the attractions according to their perception of interest as a place to visit. In this Q-sort study, +5 indicates »This has crucial importance for me while choosing a destination « and -5 indicates »This has no importance for me while choosing a destination. " The number of attractions for the individual columns was constructed as close as possible to a normal distribution (1-2-4-7-12-17-12-7-4-2-1).

The numbers of visitors in the partial territorial units of the study area were taken from our previous research (Navrátil et al. 2012a). The methodology is described in detail in Navrátil et al. (2012a, 52 and 53). The GIS shapefile was used for the subsequent calculations in this article, which provided data on the total visitor frequency model of partial territorial units in a regular hexagonal net according to input data for 2010.

\subsection{Data Processing and Analysis}

The appeal of the area was evaluated in the identical artificial spatial units as the visitor frequency model of the study area: a regular hexagonal network with hexagons approximately $3 \mathrm{~km}^{2}$ (Navrátil et al. 2012a). The presence of an attraction (in the case of a point shapefile) was ascertained in each hexagon. Polygonal and linear shapes had to be converted to points first. Lines and polygons were cut by the shape of the hexagonal artificial spatial units and then centroids of the new polygons and lines were calculated. Then the presence of these points in hexagons was ascertained.

The typology of the partial territorial units was based on a combination of the presence of the individual attraction types in each hexagonal artificial spatial unit. The TWINSPAN hierarchical divisive method (Hill 1979) was used. The division in TWINSPAN is made according to the results of the correspondence analysis on the first axis. This is processed by the settings of the »cut level « analytical operation that was chosen for levels $0 \%, 5 \%$, and $25 \%$ in the representation of the attractions. This division was made in four degrees. The attractions with the highest fidelity were used (i.e., the highest fidelity to the group); those with a $\varphi$-coefficient value (Tichý 2002) greater than 10 were used to describe the newly created groups. 
Acta geographica Slovenica, 54-1, 2014

Table 1: $\varphi$-coefficient values of core resources for spatial attraction types (only resources with a $\varphi$-coefficient greater than 10 for at least one type of area are shown).

\begin{tabular}{|c|c|c|c|c|c|c|c|c|c|}
\hline & $\begin{array}{c}1 . \\
\text { Important } \\
\text { non-forest } \\
\text { habitats }\end{array}$ & $\begin{array}{l}2 . \\
\text { Wooded } \\
\text { rocky } \\
\text { slopes }\end{array}$ & $\begin{array}{c}3 . \\
\text { Abandoned } \\
\text { border } \\
\text { areas }\end{array}$ & $\begin{array}{l}4 . \\
\text { Upland } \\
\text { plains }\end{array}$ & $\begin{array}{c}5 . \\
\text { Wild } \\
\text { river } \\
\text { valleys }\end{array}$ & $\begin{array}{c}6 . \\
\text { Mountain } \\
\text { foothills }\end{array}$ & $\begin{array}{l}7 . \\
\text { Rural } \\
\text { areas }\end{array}$ & $\begin{array}{l}8 . \\
\text { Urban } \\
\text { areas }\end{array}$ & $\begin{array}{c}9 . \\
\text { Pond } \\
\text { areas }\end{array}$ \\
\hline Number of territories & 161 & 226 & 226 & 144 & 210 & 951 & 2055 & 710 & 218 \\
\hline Peat bog & 63.2 & 10 & - & - & - & - & - & - & - \\
\hline Virgin or near-virgin forest & 5.1 & 57.2 & - & - & - & - & - & - & - \\
\hline Rocks and crags & 9.5 & 40.5 & - & - & - & - & - & - & - \\
\hline Mountain landscape & 0.2 & 13 & 1.7 & $\begin{array}{ll}- \\
-\end{array}$ & 3.3 & - & - & - & - \\
\hline Pre-WWII fortification & - & 10.3 & 3.7 & - & 2 & $\begin{array}{lll}- \\
\end{array}$ & 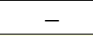 & - & - \\
\hline Dilapidated village & 9 & 3.7 & 45.6 & - & - & - & - & - & - \\
\hline Spring with drinking water & - & 7.2 & 26.6 & - & - & $\begin{array}{lll}- \\
-\end{array}$ & - & - & - \\
\hline Groomed ski hill or slope & - & 8.8 & 12.9 & 2.5 & $\begin{array}{lll}- \\
-\end{array}$ & $\begin{array}{llll}- & \\
\end{array}$ & - & & - \\
\hline Carved valley landscape & - & - & - & - & 80.7 & $\begin{array}{lll}- \\
-\end{array}$ & 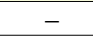 & - & - \\
\hline Climbing opportunity & - & 6.7 & $\begin{array}{ll}- \\
-\end{array}$ & - & 20 & - & - & - & - \\
\hline Cave & - & 1 & - & - & 11.4 & 0.8 & 0.3 & 0.8 & - \\
\hline Tower house & - & - & - & - & 10.8 & - & - & 3.9 & - \\
\hline $\begin{array}{l}\text { Ruins of tower house } \\
\text { or other monument }\end{array}$ & - & 1.2 & - & - & 10.2 & - & - & 1.7 & - \\
\hline $\begin{array}{l}\text { Predominantly agricultural } \\
\text { landscape }\end{array}$ & - & - & - & - & - & - & - & 52.6 & - \\
\hline Church & - & - & - & - & 1.4 & - & - & 35.7 & - \\
\hline Historical town building & - & - & - & - & 0.9 & - & - & 25.9 & 1.9 \\
\hline Castle & - & - & - & - & 3.1 & - & 1.2 & 20.3 & - \\
\hline Tennis court & - & - & - & - & 1.9 & - & - & 16.4 & 3.7 \\
\hline \multicolumn{10}{|l|}{ Remnants of fortresses } \\
\hline Town monument reservation & - & - & - & - & 4.8 & - & - & 11.7 & 4.5 \\
\hline Jewish cultural monument & - & - & - & - & 9.9 & - & - & 11 & - \\
\hline Calvary chapel & $\begin{array}{lll}- & \\
\end{array}$ & $\begin{array}{llll}- & & & \\
\end{array}$ & $\begin{array}{llll}- & & & \\
-\end{array}$ & $\begin{array}{llll}- & & & \\
-\end{array}$ & 8.9 & $\begin{array}{llll}- & & & \\
\end{array}$ & 5.9 & 10.9 & $\begin{array}{ll}- \\
-\end{array}$ \\
\hline Broad flood-meadow landscape & - & - & - & - & - & - & - & 5 & 45.5 \\
\hline $\begin{array}{l}\text { Dam (pond, water barrier, } \\
\text { artificial channel) }\end{array}$ & - & - & - & - & - & - & - & 2.6 & 13.1 \\
\hline $\begin{array}{l}\text { Monuments of popular } \\
\text { architecture }\end{array}$ & - & - & - & - & 3.3 & 0.9 & 2.8 & 0.5 & 10.4 \\
\hline Rare plant & 59 & 23.4 & - & - & - & - & - & - & 8.6 \\
\hline Rare animal & 54.2 & 17.1 & - & - & - & - & - & - & 9 \\
\hline $\begin{array}{l}\text { High-elevation plateau } \\
\text { landscape }\end{array}$ & 16.5 & 3.7 & 4.2 & 31.6 & - & - & - & - & - \\
\hline Flatland landscape & 13.7 & - & $\begin{array}{lll}- & & \\
-\end{array}$ & - & - & $\begin{array}{ll}- \\
-\end{array}$ & - & - & 67.5 \\
\hline Cirque landscape & - & 10.8 & $\begin{array}{lll}- \\
-\end{array}$ & 13.9 & $\begin{array}{lll}- \\
-\end{array}$ & $\begin{array}{ll}- \\
-\end{array}$ & $\begin{array}{llll}- & \\
\end{array}$ & - & - \\
\hline Recreational fishing & $\begin{array}{lll}- \\
\end{array}$ & 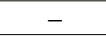 & $\begin{array}{lll}- \\
\end{array}$ & 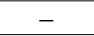 & 57.8 & $\begin{array}{lll}- \\
\end{array}$ & 0.1 & 1.5 & 13.2 \\
\hline Boating & - & - & - & - & 41.1 & - & - & - & 21.1 \\
\hline Water-powered mill or iron mill & - & - & - & - & 10.3 & - & 0.1 & 10.5 & 0.1 \\
\hline Pond landscape & - & - & - & - & - & - & 16.6 & - & 59.8 \\
\hline Town landscape & - & - & - & - & - & - & - & 20.5 & 27.3 \\
\hline $\begin{array}{l}\text { Meadow vegetation near } \\
\text { traditional farming }\end{array}$ & 18.6 & 18 & - & - & - & - & - & - & 13.2 \\
\hline $\begin{array}{l}\text { Hillsides and rocky mountain } \\
\text { ridge landscape }\end{array}$ & - & 35.3 & 38.2 & 33.6 & - & 2.5 & - & - & - \\
\hline Observation and viewpoint & - & 10.9 & 16.3 & 7.3 & - & - & - & 11.9 & - \\
\hline Highland landscape & - & - & 1.8 & - & 23.5 & 20.9 & 25.9 & 24.8 & - \\
\hline Forested landscape & $\begin{array}{lll}- \\
-\end{array}$ & $\begin{array}{lll}- \\
-\end{array}$ & 3.6 & $\begin{array}{lll}- \\
-\end{array}$ & 20.7 & 14.7 & 22.5 & 13.8 & - \\
\hline $\begin{array}{l}\text { Mixed forest, meadow, } \\
\text { and field landscape }\end{array}$ & 11.8 & 21.2 & 23.2 & 26.2 & 3.8 & 13.7 & - & - & - \\
\hline
\end{tabular}


The demand segments were identified by cluster analysis (Ward Method, Euclidean distance) of the questionnaires from both surveys (the scale of the rate of participation on partial recreational activities). The estimated credibility loss ratio was $50 \%$ as in Real et al. (2000). The questionnaires from the model segments (i.e., students) were selected from the identified clusters. The average appeal value for the particular attractions for each demand segment was calculated. The means were converted into positive values (the results of the Q-sort experiment varied between -5 to +5 ) and then transformed by power because the data were obtained from the Q-sort study. The final appeal value of each attraction type for the demand segment was relatively expressed as a share of the appeal of the partial attraction type in the maximum appeal value achieved by the most attractive attraction type. These values were assigned to a particular attraction type included in the GIS database, individually for each demand segments.

The appeal of the particular types of territory was determined as a sum of the appeal of all of the attractions located in each hexagon for the partial demand segments. The differences in the average appeal among the types of areas were investigated by one-way ANOVA with Tukey unequal N HSD post-hoc tests (Quinn and Keough 2002).

Subsequently, the development potential of the types of areas was assessed. First it was necessary to standardize the data on the appeal rate and data from the visitor frequency model to make the calculation possible. The development potential was evaluated as the simple difference between the standardized appeal values and standardized values of visitor frequency model in each hexagonal artificial spatial unit. The differences in the average development potential (among the types of areas) were investigated using one-way ANOVA with Tukey unequal N HSD post-hoc tests.

The adjustments of the spatial data were carried out using Quantum GIS software (Athan et al. 2011). STATISTICA 10.0 software (StatSoft 2011) was employed for the cluster analysis calculations and one-way ANOVA. Calculation of TWINSPAN was done using JUICE software (Tichý 2002).

\section{Results and discussion}

Nine spatial attraction types were identified in the study area. A comparison of the values of $\varphi$-coefficients of the attractions of the partial types (Table 1) and spatial distribution of these types (Figure 3) makes it possible to confirm the validity of the database that was developed. The first type, called »important non-forest habitats « (Figure 4), is typical by appeal given by the presence of important (protected) species of plants and animals associated with peat bogs and meadows. High-elevation plateaus prevail in these types of landscapes. This type can especially be found in the high elevations of the Bohemian Forest. However, they can also be found in low-basin areas in the Třeboň Protected Landscape Area, whose peat bogs are of global importance and are protected within the Ramsar Convention on Wetlands as the Třeboň peatlands and Třeboň fishponds (Chytil and Hakrová 2001).

The second type of appeal is also indicated solely by the natural place of interest. In this case, the sites are linked to wooded slopes with rocks and landscapes with hillsides and rocky mountain ridges. Therefore it was named »wooded rocky slopes " (Figure 5). It is found in the highest parts of the Bohemian Forest and the highest parts of the Nové Hrady Mountains park.

The third type is spatially complementary to the previous ones. It is called »abandoned border areas" (Figure 6) because the abandoned and ruined villages originated with the expulsion of Germans from Czechoslovakia and the subsequent establishment of the Iron Curtain after the Second World War. Springs in these villages are typical for this type. These areas offer various opportunities to develop tourism; larger non-wooded areas can be found; these offer panoramic views and make it possible for tourism providers to build downhill ski areas. In addition to the Bohemian Forest and the Nové Hrady Mountains, this type can also be found in the Nová Bystřice Uplands (Cz. Novobystřická vrchovina).

The fourth type can be described as "upland plains « (Figure 7) because it is almost exclusively connected to high plateau areas in Bohemian Forest National Park and its appeal is especially due to its flat relief and adjacent forested cirque and slope areas. The plains themselves represent a unique type of landscape and are the largest Central European remnant from the Paleogene Period up to the Tertiary, with the paleo-relief character of the peneplain (Demek and Mackovčin 2006).

The appeal of the fifth type is determined by deep valleys with opportunities for fishing and boating. Pseudo-karst caves, scenic overlooks, tower houses, water-powered mills, iron mills, and opportunities 


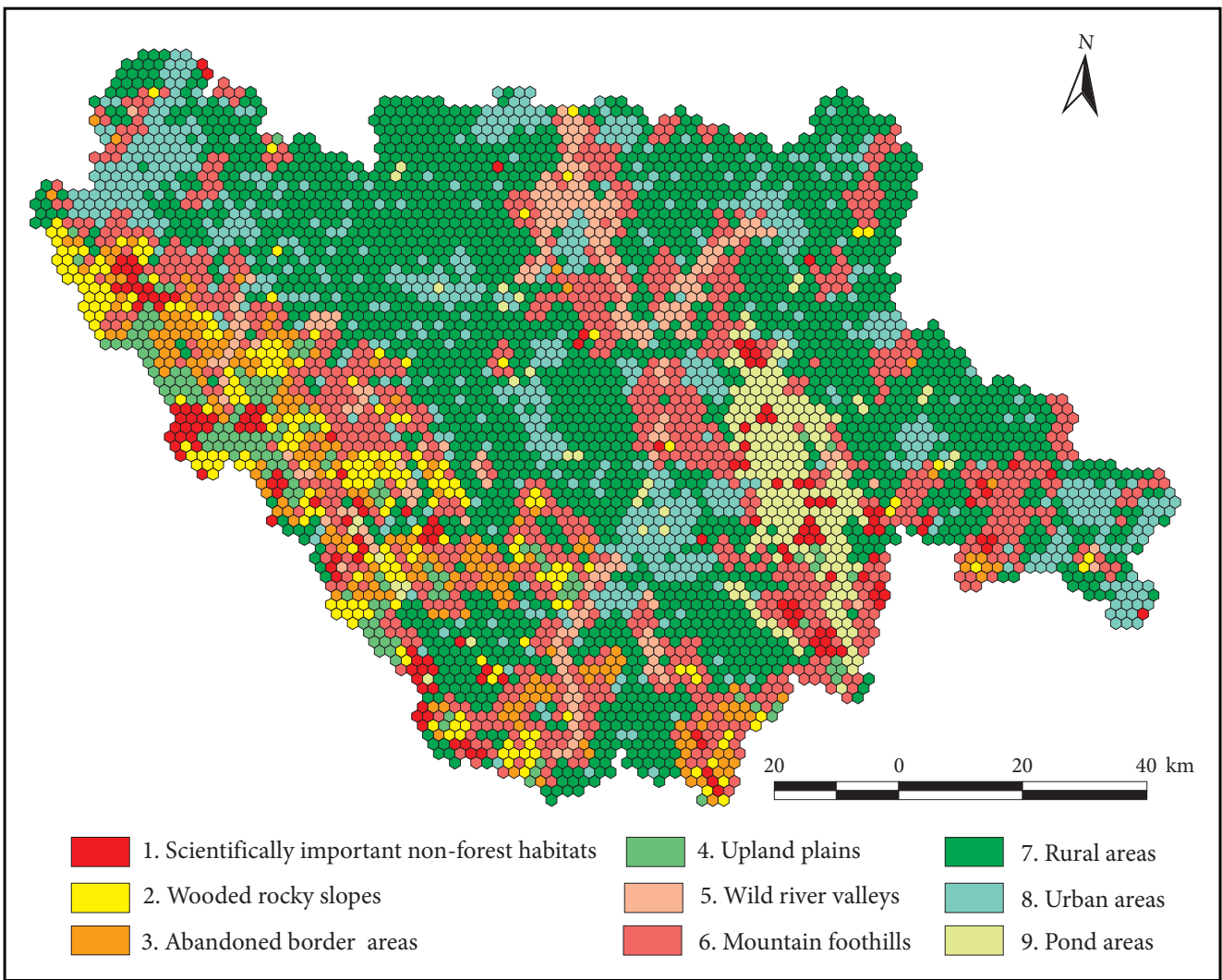

Figure 3: Appeal types in the Bohemian Forest and South Bohemia tourism regions; TWINSPAN results are displayed.

for rock climbing are linked to these valleys. This type has been named »wild river valleys « and can be found in the upper course and springs of the Otava River, along the Vltava River from Vy̌ší Brod to Boršov and from Zvíkov to Orlík, and on the Lužice River from Tábor to its confluence with the Vltava River.

The sixth type is formed by hilly Hercynian relief with a mix of forests, meadows, and arable land. It is named »mountain foothills « and it covers the lower elevations of the Bohemian Forest, the Nové Hrady Mountains and its foothills, and some other areas.

The seventh type covers the largest parts of the study area and its typical attractions are not significantly different from the previous type. However, the pond landscapes and landscapes without forests are more important for this type of landscape (Havlicek et al. 2012), and so it was named »rural areas« (Konečný 2014).

Some areas were separated from the seventh type and they create an eighth type with a very typical presence of urban and exclusively agricultural landscapes with both urban and rural settlements that are important from a cultural and historical point of view. This type is completed by the presence of cultural and historical core tourism sites (Ritchie and Crouch 2003) such as churches, castles, and places of Jewish history. This type is called »urban areas«.

The last type is determined by a flat landscape with ponds and the presence of historical urban and rural settlements, as well as important water features that are suitable for boating and fishing. This type is almost solely located in the central part of the Třeboň Protected Landscape Area and is named "pond areas«.

From the nine landscape appeal types identified in the study area, two types were selected whose appeal base is the presence of rare natural features dominated by peat bogs and natural habitats with scrub undergrowth or natural forests. In addition, many vulnerable ecosystems are linked to these types of plains, wild mountain river valleys, and vertically based ecosystems (Chytrý 2012). 

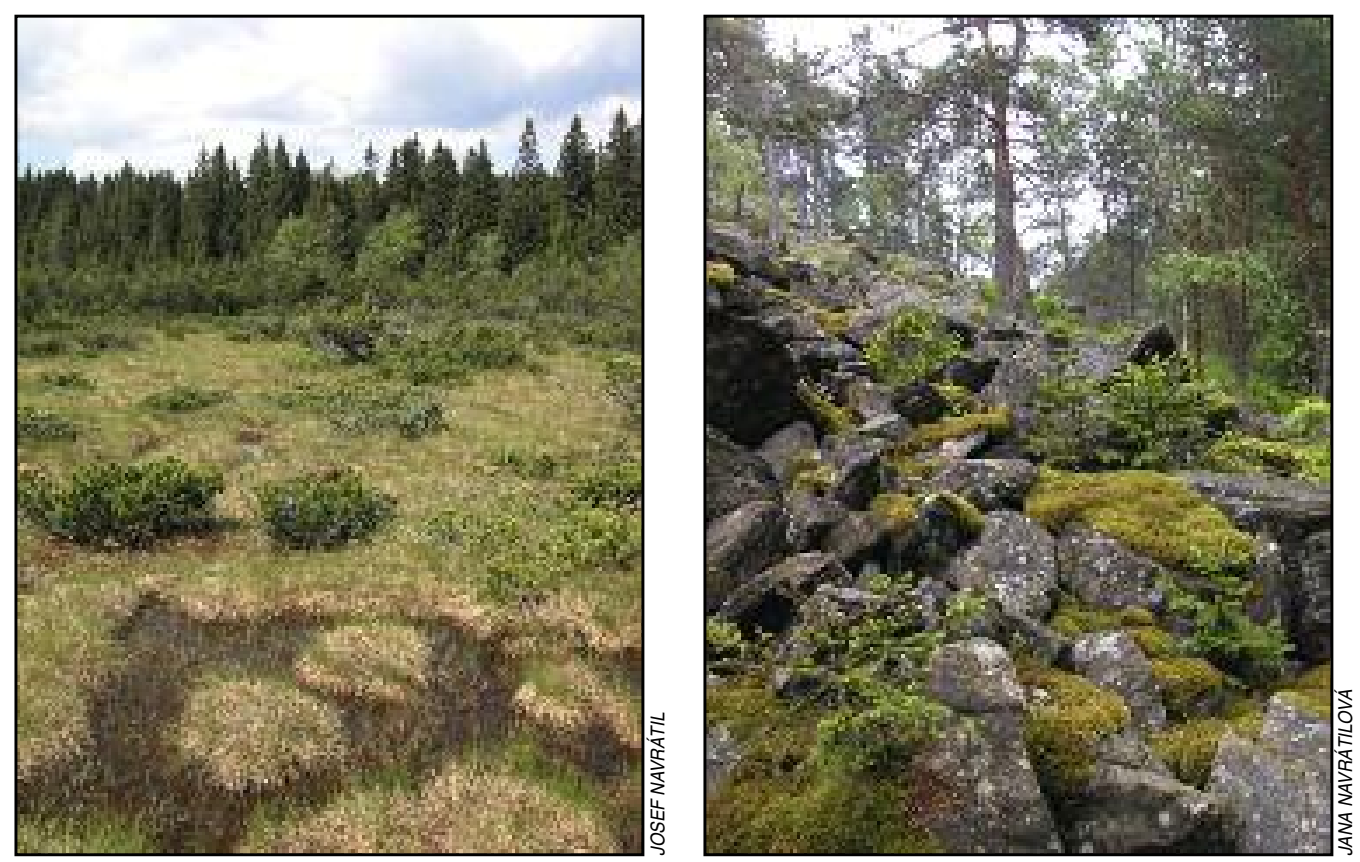

Figure 4: Important non-forest habitats: the Moss Peat Bog (Cz. Rokytecká slat'), the Bohemian Forest (left) and wooded rocky slopes of the Giant's Castle Mountain (Cz. Obř hrad), the Bohemian Forest.

The individual types were primarily defined based on appearance (Ritchie and Crouch 2003). This is due to the natural combination of attraction types based on the natural environment (Hall and Lew 2006) and the opportunities for human use (Crang 1998). Nevertheless, a type dependent on cultural and historical attractions was also found (McKercher and du Cros 2008).

The total appeal for each hexagonal artificial spatial unit was then calculated. The most significantly attractive areas are those in the first and the second types, which cover important non-forest habitats and wooded rocky slopes (Figure 8). The following types have a medium appeal rate: wild river valleys, urban areas, abandoned border areas, and pond areas. A low appeal rate was calculated for rural areas, mountain foothills, and upland plains.

The comparison of the appeal in each hexagonal artificial spatial unit with the visitor frequency model makes it possible to identify areas where a relative surplus of appeal (with respect to visitors) is evident. There are two such area types: important non-forest habitats and wooded rocky slopes (Figure 9). A moderate appeal surplus was also detected in urban areas as well as in rural areas. However, visitor frequency is high in upland plains and pond areas (and less so for other types). Thus highly vulnerable areas are most important, where potentially increasing visitor numbers could impact other aspects of these areas (Pickering 2010), especially nature and landscape conservation (Bushell et al. 2007). Thus, using these areas for tourism activities is very problematic and undesirable because of continued degradation of the natural environment (Boucníková and Kučera 2005; Guth and Kučera 2005).

\section{Conclusion}

From the point of view of territory type, this model has identified naturally important non-forest habitats and wooded rock slopes as being the most attractive for tourism development. They are highly visited and they also have high further development potential. These areas are also among the most important ones from the point of view of nature and landscape protection in Central Europe (Chytrý 2012). This aspect of the research corresponds to reality because conflicts regarding different utilization of this study 


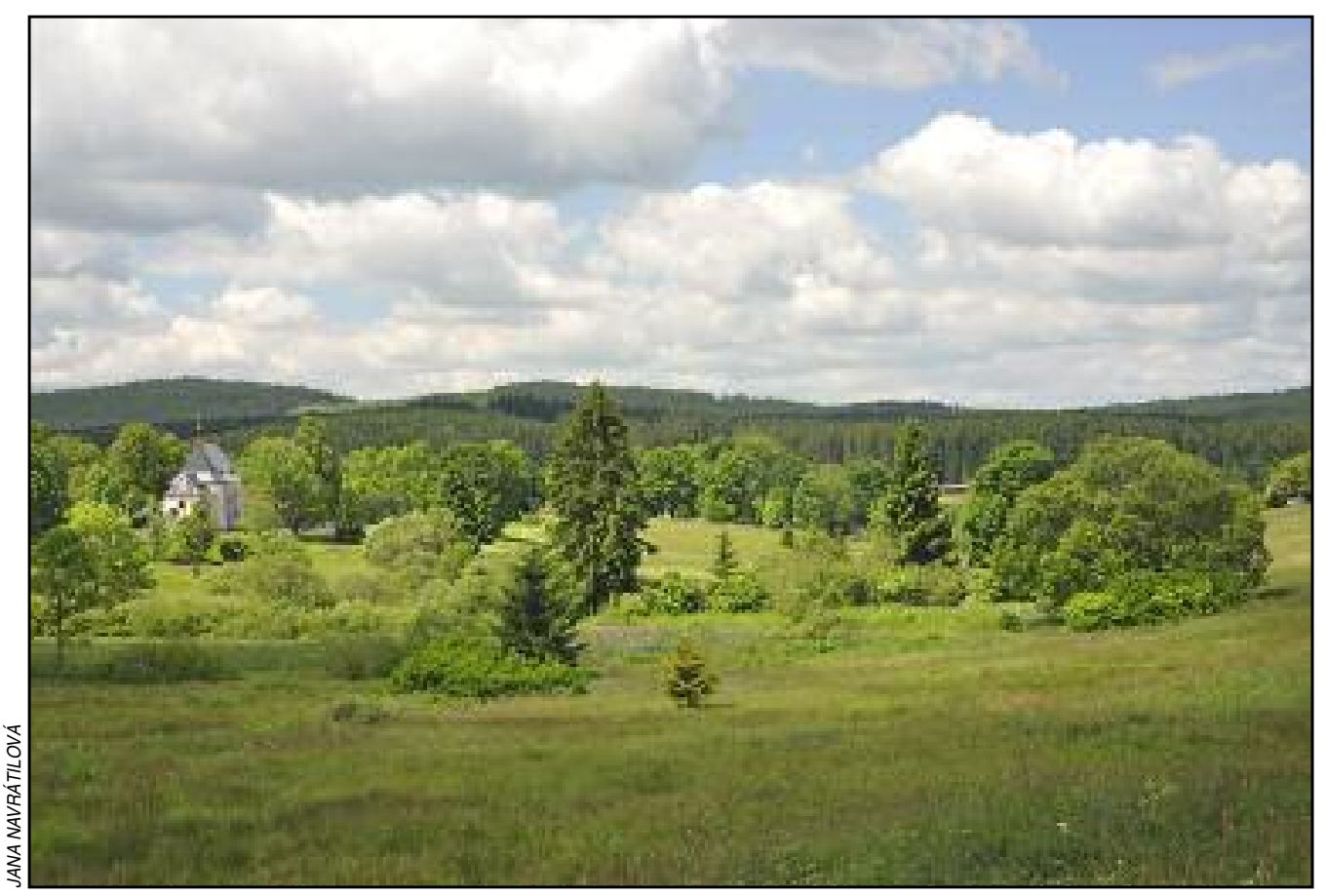

Figure 6: Abandoned border areas: the village of Pohoří na Šumavě, the Nové Hrady Mountains.

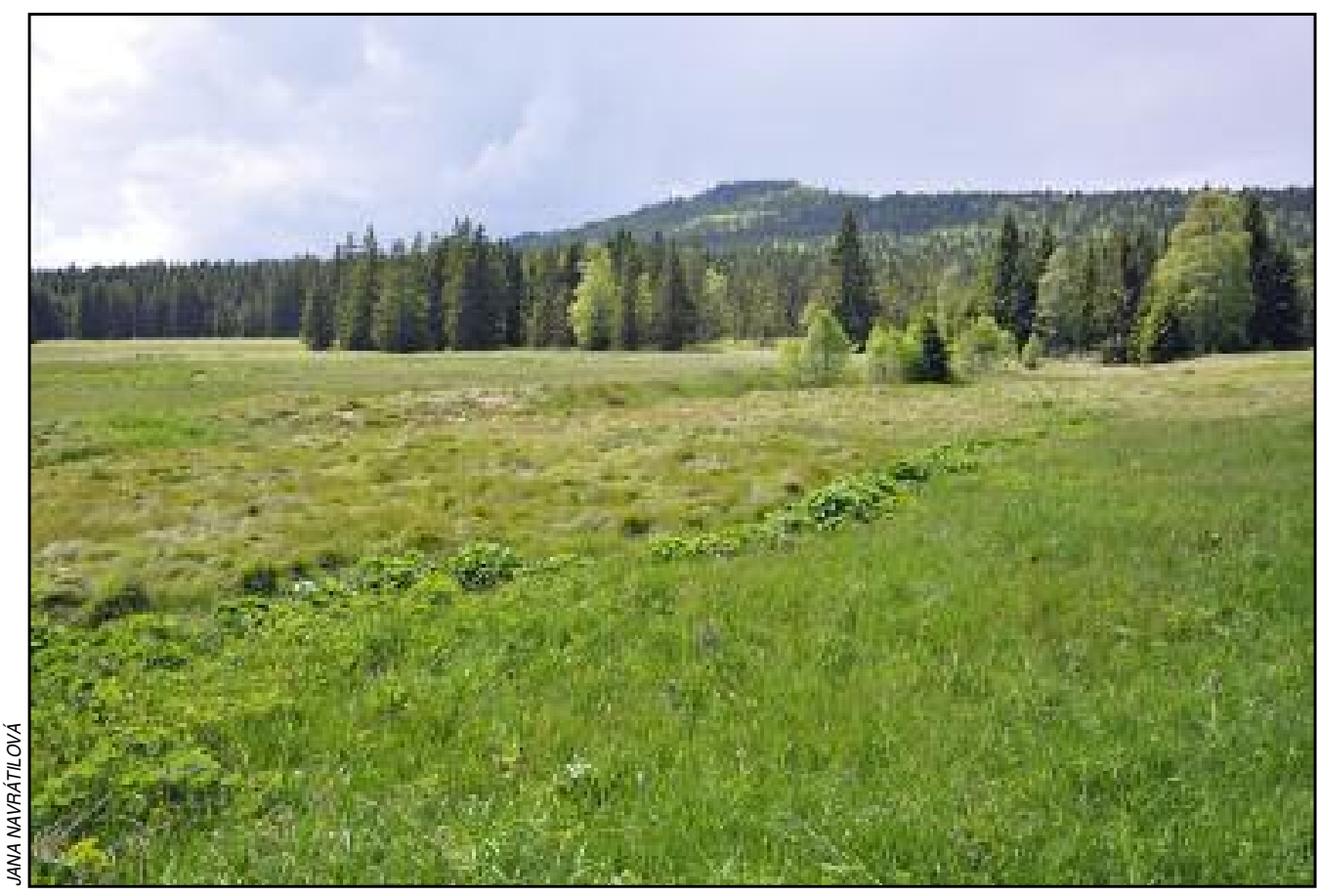

Figure 7: Upland plains: the Gerl Glassworks (Cz. Gerlova Hut'), the Bohemian Forest. 


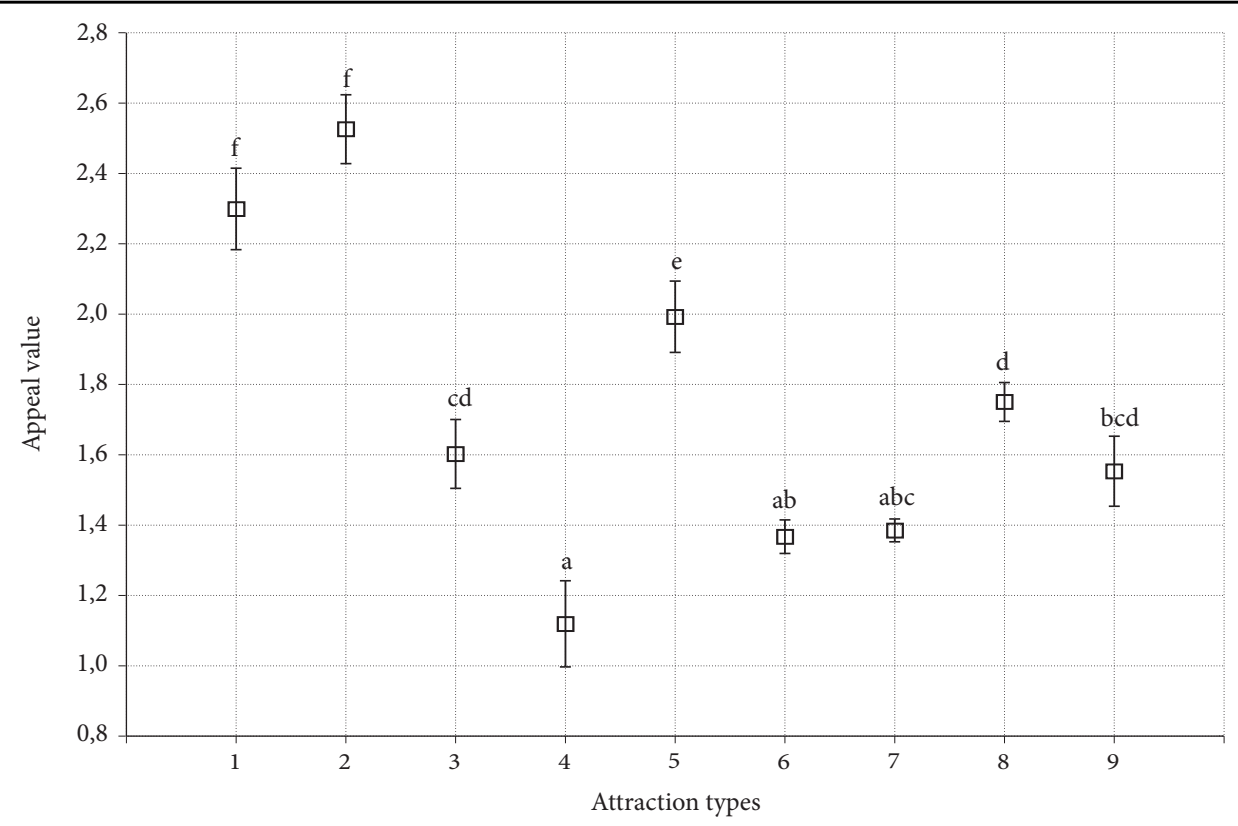

Figure 8: Appeal of individual attraction types (the numbers on the $x$ axis correspond to the landscape types in Figure 3 and Appendix 1). The averages and $95 \%$ intervals of reliability are displayed. Result of one-way ANOVA $(F=108.95 ; d$. $f .=8 ; p<0.001)$. The averages marked by the same letter do not differ significantly (HSD Tukey post-hoc test for non-equal number of $n, p>0.05, n=4,901$ ).

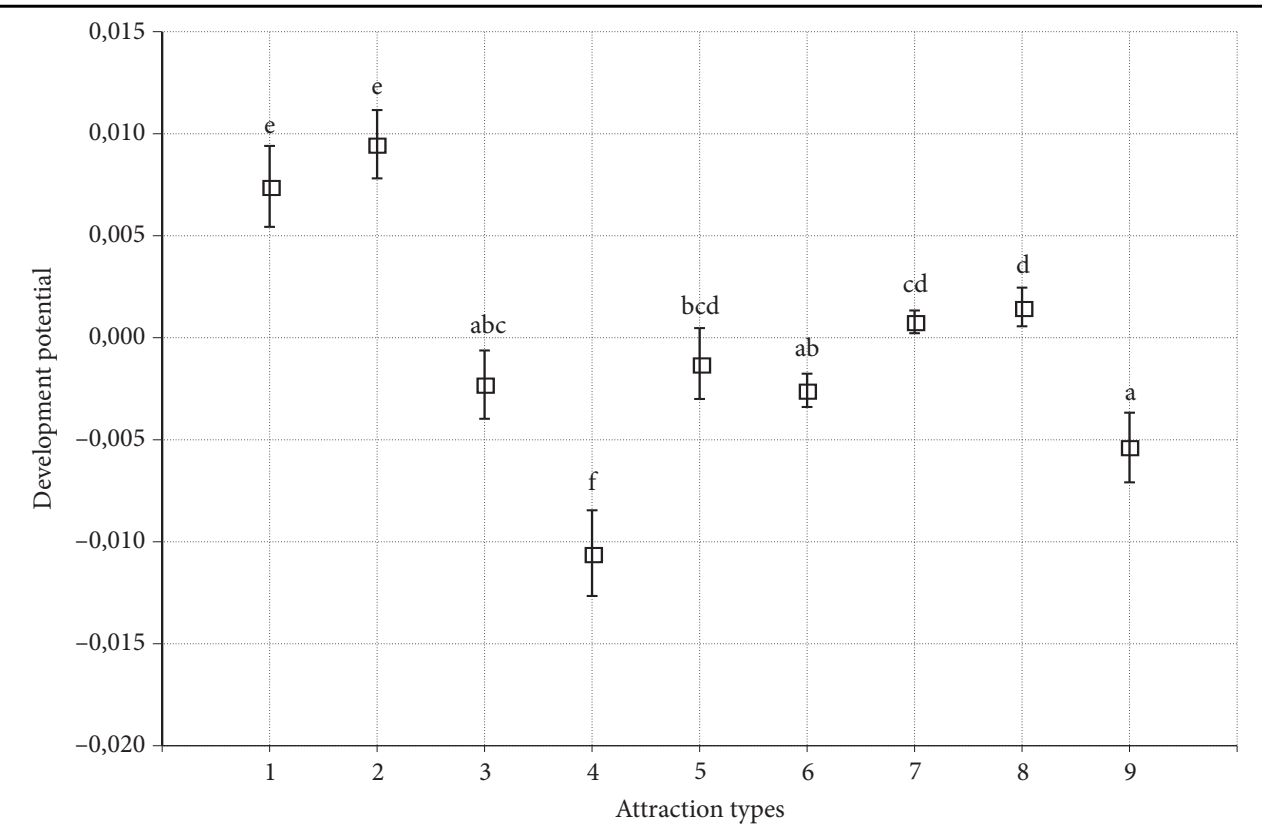

Figure 9: Identification of tourism development areas by attraction type (the numbers on the $x$ axis correspond to landscape types in Figure 3 and Appendix 1). The averages and $95 \%$ intervals of reliability are displayed. Result of one-way ANOVA ( $F=47.15 ;$ d. $f .=8 ; p<0.001)$. The averages marked by the same letter do not significantly differ (HSD Tukey post-hoc test for non-equal number of $n, p>0.05, n=4,901$ ). 
area have become an important political issue. It is especially a topic associated with the Bohemian Forest National Park Administration, which is the largest of this kind in the Czech Republic. With respect to the importance of the Bohemian Forest Tourist Region from the tourism and nature/landscape conservation points of view (cf. Prach 2010), these protected natural sites are constantly exposed to the pressure of seeking open free access (see Novinky 2010). Under such pressure along with the development drive of tourism (Hall and Page 2006), such areas are currently unable to cope with this stress (Holden 2008; Plesník 2010). With future increases in large-scale recreational tourism, the pressure of both tourists and tourism infrastructure will probably grow (Novinky 2011). Other regions in the Czech Republic, such as the Beskid Mountains with the Beskid Landscape Protected Area (Cz. Chráněná krajinná oblast Beskydy; Havrlant 2001), the Jeseník Mountains with the Jeseník Landscape Protected Area (Cz. Chráněná krajinná oblast Jeseníky; Havrlant 2010), or the Dyje Valley National Park (Cz. Národní park Podyjí; Foret and Klusáček 2011) have experienced a similar situation as well.

The methodological approach presented is based on a combination of different approaches for evaluating the appeal of the core sources of tourism (Ritchie and Crouch 2003), whose core lies not in typologicalspatial analysis, contrary to the bulk of similar studies based on the cultural environment (e.g., Topole 2009; Vujičić et al. 2011), but in analysis of the relations of visitors to these areas. These analyses are not exceptional in Central Europe, of course (e.g., Polajnar 2008; Pompurová 2011); nevertheless they are not usually directly linked to concrete spatial elements and are usually related to the selection of tourism products or are the result of expert assessments (Bína 2002). The examples of the Bohemian Forest and South Bohemia tourism regions have proved that it is necessary and appropriate to employ the combined approach to evaluate of the importance of elements of natural and cultural-historical systems for the next stage of tourism development.

\section{Acknowledgements}

The authors express their gratitude to the nineteen students that acted as data collection assistants and all those that participated in the questionnaires. The authors would also like to thank Karel Kirchner and two anonymous reviewers for their remarks on early versions of this article. This article was written with support from the Czech Science Foundation: GACR P404/12/0334 »Factors of visitors' relation to the ambience of attractions in vulnerable areas."

\section{References}

Anderson, D. H., Brow, P. J. 1984: The displacement process in recreation. Journal of leisure research 16-1. Athan, T., Blazek, R., Contreras, G., Dassau, O., Dobias, M., Ersts, P., et al. 2011: Quantum GIS user guide, Version 1.7.0 »Wroclaw.« Internet: http://download.osgeo.org/qgis/doc/manual/qgis-1.7.0_user_ guide_en.pdf (20.10.2011).

Barry, J., Proops, J. 1999: Seeking sustainability discourses with Q methodology. Ecological economics 28-3. DOI: http://dx.doi.org/10.1016/S0921-8009(98)00053-6

Benthien, B. 1997: Geographie der Erholung und des Tourismus. Erfurt.

Bína, J. 2002: Hodnocení potenciálu cestovního ruchu v obcích České republiky. Urbanismus a územní rozvoj 5-1.

Boucníková, E., Kučera, T. 2005: How natural and cultural aspects influence land cover changes in the Czech Republic? Ekológia 24-1.

Bushell, R., Staiff, R., Eagles, P. F. J. 2007: Tourism and protected areas: Benefits beyond boundaries. Tourism and protected areas: benefits beyond boundaries. Waterloo.

Cetkovský, S., Klusáček, P., Martinnát, S., Zapletalová, J. 2007: Some aspects of cross-border cooperation in Euroregions of the Czech Republic: An example of the Šumava Region. Moravian geographical reports $15-1$.

Christofakis, M. 2010: Strategic options for tourism impacts on local sustainability: A conceptual approach. Local economy 25-7. DOI: http://dx.doi.org/10.1080/02690942.2010.532357

Chubb, M., Chubb, H. 1981: One third of our time? An introduction to recreation behaviour and resources. New York. 
Chytil, J., Hakrová, P. (eds.) 2001: Wetlands of the Czech Republic - The list of wetland sites of the Czech Republic. Mikulov.

Chytrý, M. 2012: Vegetation of the Czech Republic: diversity, ecology, history and dynamics. Preslia 84-3. Crang, M. 1998: Cultural geography. London.

Demek, J., Mackovčin, P. 2006: Zeměpisný lexikon ČR. Hory a nížiny. Praha.

Doody, D., Kearney, P., Barry, J., Moles, R., O'Regan, B. 2009: Evaluation of the Q-method as a method of public participation in the selection of sustainable development indicators. Ecological indicators 9-6. DOI: http://dx.doi.org/10.1016/j.ecolind.2008.12.011

Foret, M., Klusáček, P. 2011: The importance of the partnership and cooperation in the regional development exampled on Znojmo region. Acta universitatis agriculturae et silviculturae Mendelianae Brunensis 59-4. DOI: http://dx.doi.org/10.2478/s11532-011-0045-3

Geneletti, D., Dawa, D. 2009: Environmental impact assessment of mountain tourism in developing regions: A study in Ladakh, Indian Himalaya. Environmental impact assessment review 29-4. DOI: http://dx.doi.org/10.1016/j.eiar.2009.01.003

Goeldner, C. R., Ritchie, J. R. B. 2009: Tourism: Principles, practices, philosophies. Hoboken.

Gunn, C. A. 1997: Vacationscape: Developing tourist areas. London.

Guth, J., Kučera, T. 2005: Natura 2000 habitat mapping in the Czech Republic: Methods and general results. Ekológia 24-1.

Hall, C. M., Lew, A. A. 2009: Understanding and managing tourism impacts: an integrated approach. London. Hall, C. M., Page, S. J. 2006: The geography of tourism and recreation. Environment, place and space. London.

Havlicek, M., Krejcikova, B., Chrudina, Z., Svoboda, J. 2012: Long-term land use development and changes in streams of the Kyjovka, Svratka and Velicka river basins (Czech Republic). Moravian geographical reports 20-1.

Havrlant, J. 2001: The Beskydy Mountains - specific features and problems of the tourist area. Geografski obzornik 48-2.

Havrlant, J. 2010: The recreational potential of the Jeseníky Region (Czech Republic and the influence of soft factors on its development). Moravian geographical reports 18-1.

Heydendael, A. 2002: Sustainable tourism within the context of the ecosystem approach. Tourism, biodiversity and information. Amsterdam.

Hill, M. O. 1979: TWINSPAN - A FORTRAN program for arranging multivariate data in an ordered two-way table by classification of the individuals and attributes. Ithaca.

Holden, A. 2008: Environment and Tourism. London.

Horner, S., Swarbrooke, J., 1996: Marketing tourism, hospitality and leisure in Europe. London.

Jamal, T. B., Stein, S. M., Harper, T. L., 2002: Beyond labels - pragmatic planning in multistakeholder tourism-environmental conflicts. Journal of planning education and research 22-2. DOI: http://dx.doi.org/ 10.1177/0739456X02238445

Juutinen, A., Mitani, Y., Mantymaa, E., Mäntymaa, E., Shoji, Y., Siikamäki, P., Svento, R. 2011: Combining ecological and recreational aspects in national park management: A choice experiment application. Ecological economics 70-6. DOI: http://dx.doi.org/10.1016/j.ecolecon.2011.02.006

Knox, P. L., Marston, S. A. 2001: Places and regions in global context: human geography. New Yersey.

Konečný, O. 2014: Geographical perspectives on agritourism in the Czech Republic. Moravian Geographical Reports 22-1. DOI: 10.2478/mgr-2014-0002

Kostrowicki, A.S. 1970: Zastosowanie metod geobotanicznych w ocenie przydatności terenu dla potrzeb rekreacji i wypoczynku. Przegląd geograficzny, 42-4

Kučera, T. 2005: Red book on habitats of the Czech Republic. Internet: http://www.biomonitoring.cz/ biotop_cerv_kn/texty/8/index.html> (24.4.2013).

Kušen, E. 2010: A system of tourism attractions. Tourism - an international interdisciplinary journal 58-4.

Lau, G., McKercher, B. 2006: Understanding tourist movement patterns in a destination: A GIS approach. Tourism and hospitality research 7-1. DOI: http://dx.doi.org/10.1057/palgrave.thr.6050027

Marion, J. L., Leung, Y. 2001: Trail resource impact and an examination of alternative assessment techniques. Journal of park and recreation administration 19-3.

Mariot, P. 1983: Geografia cestovného ruchu. Bratislava. 
McClanahan, T. R., Cinner, J., Kamukuru, A. T., Abunge, C., Ndagala, J., 2008: Management preferences, perceived benefits and conflicts among resource users and managers in the Mafia Island Marine Park, Tanzania. Environmental conservation 35-4. DOI: http://dx.doi.org/10.1017/S0376892908005250

McKercher, R., du Cros, H. 2008: Cultural tourism: partnership between tourism and cultural heritage. London.

Navrátil, J., Pícha, K., Hřebcová, J. 2010: The importance of historical monuments for domestic tourists: The case of south-western Bohemia (Czech Republic). Moravian Geographical Reports 18-1.

Navrátil, J., Švec, R., Pícha, K., Doležalová, H. 2012a: The location of tourist accommodation facilities: A case study of the Šumava Mts. and South Bohemia tourist regions (Czech Republic). Moravian Geographical Reports 20-3.

Navrátil, J., Pícha, K., Martinát, S. 2012b: Spatial differentiation of the nature trails in the large-area protected natural territories. Acta universitatis Palackianae Olomucensis facultas rerum naturalium geographica 43-2.

Navrátil, J., Pícha, K., Martinát, S., Knotek, J., Kučera, T., Balounová, Z., White Baravalle Gilliam, V.L., Švec, R., Rajchard, J. 2013a: The model of identification of the tourism development areas: A case study of the Šmava Mts. and South Bohemia Tourist Regions (Czech Republic). Moravian geographical reports 21-1. DOI: http://dx.doi.org/10.2478/mgr-2013-0003

Navrátil, J., Pícha, K., Knotek, J., Kučera, T., Navrátilová, J., Rajchard, J., White Baravalle Gilliam, V. L. 2013b: The comparison of attractiveness of tourist sites for ecotourism and mass tourism: The case of waters in mountainous protected areas. Tourismos: An international multidisciplinary journal of tourism 8-1.

Nepal, S. K., Nepal, S. A. 2004: Visitor impacts on trails in the Sagarmatha (Mt. Everest) National Park, Nepal. AMBIO: A journal of the human environment 33-6. DOI: http://dx.doi.org/10.1579/ 0044-7447-33.6.334

Novinky 2010: Šumava se má opět otevř́ít turistům, rozhodl soud. Internet: http://www.novinky.cz/domaci/ 219798-sumava-se-ma-opet-otevrit-turistum-rozhodl-soud.html (5.12.2011).

Novinky 2011: První zónu parku Šumava protne lanovka, schválili jihočeští radní. Internet: http://www.novinky.cz/ domaci/243339-prvni-zonu-parku-sumava-protne-lanovka-schvalili-jihocesti-radni.html (5.12.2011).

Olwig, K., Olwig, K. 1979: Underdevelopment and the development of »natural « parks ideology. Antipode 11-2.

Palmer, J. F., Hoffman, R. E. Rating reliability and representation validity in scenic landscape assessments. Landscape and urban planning 54-1. DOI: http://dx.doi.org/10.1016/S0169-2046(01)00133-5

Pickering, C. M. 2010: Ten factors that affect the severity of environmental impacts of visitors in protected areas. AMBIO: A journal of the human environment 39-1. DOI: http://dx.doi.org/10.1007/s13280-009-0007-6

Plesník, P. 2010: Vplyv cestovného ruchu na biosféru. Acta geographica universitatis Comenianae 54-1.

Polajnar, K. 2008: Public awareness of wetlands and their conservation. Acta geographica Slovenica 48-1. DOI: http://dx.doi.org/10.3986/AGS48105

Pompurová, K. 2011: Atraktívnost' Slovenska pre vybraný segment návštěvníkov. E+M Ekonomie a Management 14-2.ň

Prach, K. 2010: Divočina v české krajině. Vesmír 89-12.

Quinn, G. P., Keough, M. J. 2002: Experimental design and data analysis for biologists. Cambridge.

Real, E., Arce, C., Sabucedo, J. M. (2000). Classification of landscapes using quantitative and categorical data, and prediction of their scenic beauty in north-western Spain. Journal of environmental psychology 20-4. DOI: http://dx.doi.org/10.1006/jevp.1999.0129

Ritchie, J.R.B., Crouch, G.I. 2003: The competitive destination: A sustainable tourism perspective. Wallingford.

Robinson, G. M. 1998: Methods and techniques in human geography. London.

StatSoft 2011: Electronic statistics textbook. StatSoft, Tulsa. Internet: http://www.statsoft.com/textbook/ (12.10.2011).

Steelman, T. A., Maguire, L. A. 1999: Understanding participant perspectives: Q-methodology in national forest management. Journal of policy analysis and management 18-3.

Švec, R., Navrátil, J., Pícha, K., \& White Baravalle Gilliam, V.L. 2012: The perception of the quality of accommodation establishments' product. DETUROPE 4-2.

Tichý, L. 2002: JUICE, software for vegetation classification. Journal of vegetation science 13-3. DOI: http://dx.doi.org/10.1111/j.1654-1103.2002.tb02069.x 
Topole, M. 2009: Potential for tourism in the demographically threatened region of Jurklošter. Acta geographica Slovenica 49-1. DOI: http://dx.doi.org/10.3986/AGS49104

Vasiljević, D. A., Marković, S. B., Hose, T. A., Smalley, I., O'Hara-Dhand, K., Basarin, B., Lukić, T., Vujičić, M. D. 2011: Loess towards (geo) tourism - proposed application on loess in Vojvodina region (north Serbia). Acta geographica Slovenica 51-2. DOI: http://dx.doi.org/10.3986/AGS51305

Vujičić, M. D., Vasiljević, D. A., Marković, S. B., Hose, T. A., Lukić, T., Hadžić, O., Janićević S. 2011: Preliminary geosite assessment model (GAM) and its application on Fruška gora mountain, potential geotourism destination of Serbia. Acta geographica Slovenica 51-2. DOI: http://dx.doi.org/10.3986/AGS51303

Wall, G. 1997: Tourism attractions: points, lines, and areas. Annals of tourism research 24-1. DOI: http://dx.doi.org/10.1016/S0160-7383(96)00039-4

Weaver, D. 2006: Sustainable tourism. London.

Weidenfeld, A., Butler, R. W., Williams, A. M. 2010: Clustering and compatibility between tourism attractions. International journal of tourism research 12-1. DOI: http://dx.doi.org/10.1002/jtr.732

Williams, S. 1998: Tourism geography. London.

Wood, E. M. 2002: Ecotourism: Principles, practices and policies for sustainability. Paris. 